Institute of $\mathbf{F}_{\text {ood and }} \mathbf{A}_{\text {gricultural }} \mathbf{S}_{\text {ciences }}$

\title{
Florida Solid and Hazardous Waste Regulation Handbook: Clean Water Act (CWA) ${ }^{1}$
}

Michael T. Olexa, Aaron Leviten, and Kelly Samek ${ }^{2}$

\section{What Is the Clean Water Act (CWA)?}

The purpose of the Clean Water Act is to maintain and restore the quality of the waters of the United States. The definition of waters is broad, including all waters subject to tidal movements, reaching between states, or used in interstate or foreign commerce. These include:

- territorial seas and larger bodies of water.

- lakes, streams, rivers, ponds and other small water bodies if they have even a remote potential to affect interstate commerce or people involved in interstate commerce.

- wetlands, which are generally defined as lands that are covered periodically with enough water to support vegetation adapted to a wetlands environment.

Primarily through its discharge permitting requirements, the statute limits the amounts of pollutants that may be released into these waters in an attempt to keep the water safe for swimming and other human uses, as well as for fish and aquatic life.
The statute also provides for the cleanup of oil spills through a revolving fund managed by the United States Coast Guard.

\section{Who Enforces the CWA?}

EPA enforces the general provisions of CWA, but dredge-and-fill permitting is enforced by the Army Corps of Engineers. EPA has established national standards for the maximum amount of pollutants that may be released under its permits. States are authorized to establish their own standards for allowable levels of pollutants, as long as such standards are at least as strict as those mandated by EPA. EPA may also delegate permitting authority to the state. Currently, Florida has been delegated enforcement of only portions of CWA, but NPDES permitting, discussed next, is still conducted by EPA.

\section{What Is NPDES?}

In 1972, the CWA authorized the National Pollutant Discharge Elimination System (NPDES) permit program to control discharge water into U.S. waters.

1. This is EDIS document FE452, a publication of the Department of Food and Resource Economics, Florida Cooperative Extension Service, UF/IFAS, University of Florida, Gainesville, FL. Published December 2003. Please visit the EDIS website at http://edis.ifas.ufl.edu.

2. Michael T. Olexa, Professor in the Department of Food and Resource Economics and Director of the Agricultural Law Center, Florida Cooperative Extension Service, UF/IFAS, University of Florida, Gainesville, FL, and Member of the Florida Bar and Chair of the Agricultural Law Committee of the Florida Bar; Aaron Leviten, Attorney in Orlando and guest lecturer on pesticide litigation at the University of Florida; and Kelly Samek, 2003 graduate of the Levin College of Law at the University of Florida.

The Institute of Food and Agricultural Sciences is an equal opportunity/affirmative action employer authorized to provide research, educationa information and other services only to individuals and institutions that function without regard to race, color, sex, age, handicap, or national origin. For information on obtaining other extension publications, contact your county Cooperative Extension Service office. Florida Cooperative Extension Service/Institute of Food and Agricultural Sciences/University of Florida/Christine Taylor Waddill, Dean. 
These permits specify:

- the amount and concentration of pollutants the holder is authorized to discharge.

- schedules directing when compliance must be achieved.

- the requirements for testing, and monthly or quarterly reporting to the permitting authority.

\section{What Is a Point Source?}

The statute requires anyone who discharges waste by a point source to have a permit. A point source is any specific, confined and measurable place from which a pollutant is or may be discharged. A good example of a point source is a pipe that is discharging pollutants. Other examples include:

- a ditch.

- a container being rinsed of pesticides.

- or any other source that may release a pollutant into a specific area.

\section{What Is a Nonpoint Source?}

Nonpoint source pollution does not have a single identifiable source; rather, it is a collection of diffuse sources such as agricultural runoffs, stormwater discharges, and return flow from agricultural irrigation systems.

\section{How Does the CWA Address Nonpoint Sources?}

The CWA was amended in 1987 to establish the Nonpoint Source Management Program (CWA Section 319). Section 319 created a grant program to provide funding for states to administer nonpoint source pollution education and monitoring projects.

\section{How do NPDES Permits Work?}

NPDES permits impose two types of limitations on point-source polluters:

- Technology-Based Effluent Limitations, which are limits on the contents of the effluent based upon the available treatment technology.
-Water-Quality-Based Effluent Limitations, which are based on the water-quality standards established for the water body (including groundwater) into which the discharge takes place.

\section{What Substances May Not Be Discharged under NPDES?}

NPDES prohibits any discharge of oil or specified hazardous substances into navigable waters. You should contact EPA with questions about disposing any toxic waste into waters of the United States.

\section{What about Dredge-and-Fill?}

CWA requires separate permits for the discharge of dredge-and-fill material into navigable waters or wetlands. Dredge-and-fill permits are issued by the Army Corps of Engineers, but EPA has a veto power over Corps-issued permits. EPA may enforce permits issued by the Corps, as well as those permits issued by a state where the permitting authority has been delegated to that state.

\section{What about Accidental Discharges (Spills)?}

The statute requires that all spills entering U.S. waters be reported immediately if the amount spilled is greater than the individual "reportable quantities" which EPA has specified for each of some 300 designated hazardous substances. Quickly reporting spills to the National Response Center (1-800-424-8802) will insulate you from criminal prosecution, but not from civil liability.

\section{What Are the Penalties under the CWA?}

The amount of criminal liability under the statute depends on whether the violator was:

- negligent and thus subject to fines up to $\$ 25,000$ per day and 1 year in prison.

- knowing of his violation and thus subject to fines up to $\$ 50,000$ per day and 3 years in prison. 
- knowing that his violation places others in serious, imminent danger and thus subject to fines up to $\$ 250,000$ and 15 years in prison.

All these penalties may be doubled for subsequent violations and some may be greater for corporations. Injunctive relief (which forces violators to cease polluting by court order) or other court-ordered relief is also available.

The statute also provides for civil and administrative penalties of up to $\$ 25,000$ per day for each violation of the statute or NPDES permit.

\section{Acknowledgments}

The authors are indebted to the personnel of both state and federal agencies who gave their time and advice in the preparation of this handbook. The authors are also indebted to the following University of Florida personnel for a review and critique of the first draft of this publication: Dr. Thomas Dean, Pesticide Education Specialist, and Dr. Norman Nesheim, Pesticide Information Coordinator. Special recognition is also due to Mr. Richard Budell of the Office of Agricultural Water Policy of the Florida Department of Agriculture and Consumer Services for providing funds for the development of this handbook.

This handbook is designed to provide an accurate, current, and authoritative summary of the principal Florida laws that directly or indirectly relate to agriculture. It should provide a basic overview of the many rights and responsibilities farmers and farmland owners have under Florida laws. The reader is provided information about these rights and responsibilities and the appropriate contacts for more detailed information. However, the reader should be aware that because the laws, administrative rulings, and court decisions on which this publication is based are subject to constant revision, portions of this publication could become outdated at any time. Many details of cited laws are also left out due to space limitations.

This handbook is distributed with the understanding that the authors are not engaged in rendering legal or other professional advice and the information contained herein should not be regarded or relied upon as a substitute for professional advice. It is not all-inclusive in providing information to achieve compliance with laws and regulations governing the practice of agriculture. For these reasons, the use of these materials by any person constitutes an agreement to hold harmless the authors, UF/IFAS, the Agricultural Law Center, and the University of Florida for any liability claims, damages, or expenses that may be incurred by any person as a result of reference to or reliance upon the information contained in this publication. 